\title{
NOGMAALS SURINAME'S WESTGRENS
}

DOOR

DR. H. D. BENJAMINS.

Senator Van Kol heeft wegens zijn gezondheidstoestand nòch aan het afdeelingsonderzoek, nòch aan de openbare behandeling van de Surinaamsche begrooting voor 1922 in de Eerste Kamer kunnen deelnemen. Dus en dit „dus" is bedroevend - werd er in het Voorloopig Verslag met geen woord gerept over het reeds lang hangende vraagstuk van de westgrens van Suriname. Wel waren er leden die den verkoop van de kolonie te berde brachten, maar niemand achtte het noodig voort te zetten de door den heer Van Kol aangewende pogingen, om in de kwestie van de grens van de kolonie met den Britschen nabuur klaarheid te brengen. En in de vergadering van 5 Mei 1922 is de begrooting van Suriname goedgekeurd.... zonder een woord van debat.

De heer Van Kol maakt geen deel meer uit van de nieuwe Eerste Kamer. Voor de gebiedsdeelen in de West is zijn uittreden een zware slag. Moge er in onzen nieuwen senaat iemand opstaan die in belangstelling voor de West niet onderdoet voor dezen onvermoeiden strijder.

De programma's der onderscheidene politieke partijen wedijveren met elkaar in betuigingen van belangstelling in deze koloniën. Aannemende, dat de beloften geen holle frazen zijn acht ik het wenschelijk ten dienste van de nieuwe Kamer bijeen te brengen wat er, helaas niet gedaan, maar geschreven is omtrent deze grenskwestie, na mijn artikel in het nummer van dit tijdschrift van December 1921 (3e jg. $\mathrm{N}^{\circ} .8$, blz. 393 vlg.) Suriname’s westgrens und kein Ende. Ook voor anderen kan het van nut zijn alles betreffende deze kwestie bijeen te hebben. 
Even weinig als de heer Van Kol in de Staten-Generaal of in de pers steun vond in zijn streven om de Regeering er toe te brengen licht in deze zaak te ontsteken, heb ik mij te verheugen gehad over medewerking van de groote pers, om hetgeen ik over deze aangelegenheid schreef, onder de aandacht van het publiek te brengen. Een gunstige uitzondering maakte Het Nieuws van den Dag, dat in zijn nummer van 24 December 1921, onder het opschrift Grenskwesties, een hoofdartikel, toegelicht met een schetskaartje, wijdde aan het door mij in het hierboven genoemde artikel en in vroegere geschriften behandelde vraagstuk. Ik haal hieruit de volgende beschouwing aan:

.... „Dit [n.l. de ontdekking van de New River door Barrington Brown] veranderde natuurlijk de heele zaak: de veel verder westelijk stroomende „Nieuwe Rivier” zou de grens moeten vormen, aangenomen - wat naar wij meenen steeds gedaan is - dat de Korantijn het Britsche en Nederlandsche gebied van elkaar afscheidt. In elk geval is dit een prachtig geval voor arbitrage, en nu de gevolgen van den wereldoorlog overal in kaart gebracht worden, is de tijd juist zeer gunstig om de kwestie met Engeland te regelen. Zeker zou 't dwaas zijn, bij voorbaat de Nederlandsche aanspraken prijs te geven, bijv. om Engeland niet te prikkelen; deze overweging zou nog kunnen gelden tijdens den oorlog, maar niet daarna. Overigens zien we geen Britsche regeering voor zoo kleingeestig aan, ten deze aan een vermeende traditie vast te houden en arbitrage te weigeren." ....

Uit een bespreking van Mr. C. F. Schoch in Neerlandia van Februari 1922 het volgende:

.... „Onder welke benaming de machtige Corantijn op het gebergte ontspringt, als New River of als Cutari, is nog steeds niet officieel met Nederland's medewerking, althans niet met medewerking van de Staten-Generaal, vastgelegd. Eene vroegere Nederlandsche Regeering kan gezwegen hebben, toen de Regeering te Londen eene grens decreteerde, maar dat kan den Nederlandschen Staat niet binden, evenmin als dit kan doen de arbitrale uitspraak van een grensgeschil tusschen Venezuela en Britsch Guyana in 1899 te Parijs tot stand gekomen, waarbij Nederland geen partij was." ....

„In ieder geval dient de Volksvertegenwoordiging te weten, hoe het inderdaad met de zaak staat, en eene vergunning tot publicatie van wat werkelijk geschiedenis is geworden kan toch moeilijk langer worden tegengehouden." .... 
Mr. Schoch geloofde, met Zola's „la vérité est en marche", dat het einde nader komt, nu, na het overlijden van het 2e Kamerlid Jhr. van Doorn, het 1ste Kamerlid Van Kol zich voor de zaak gespannen heeft.

Hierop teekende Het Koloniaal Weekblad van 9 Februari 1922 aan:

„Ongelukkig moet de heer Van Kol zich van alle werkzaamheid onthouden. Is er nu niemand in de Eerste of Tweede Kamer die de taak van hem overneemt? Uit zichzelf zal nòch de Minister van Koloniën, nòch zijn collega van Buitenlandsche Zaken op de zaak terugkomen. Bindt niemand in de Staten-Generaal den strijd aan, dan blijft de sluier over deze zaak weer hangen, wie weet voor hoe lang."

In de Tweede Kamer bleek er eenige belangstelling voor de kwestie te bestaan. In het Voorloopig Verslag betreffende de begrooting van Suriname voor 1922, vastgesteld 14 Februari 1922, lees ik:

„Eenige leden spraken hun teleurstelling er over uit, dat de Minister in antwoord op een desbetreffende vraag van het lid der Eerste Kamer den heer Van Kol verklaarde, dat de Regeering niet bereid is over te gaan tot openbaarmaking van de bescheiden betreffende de omtrent de grens tusschen Suriname en Britsch-Guyana en die tusschen Suriname en Fransch Guyana gerezen geschillen. Met name achtten zij de uitgebreidheid der briefwisseling omtrent eerstbedoelde grensquaestie geen voldoenden grond om af te zien van een publicatie, die zoowel uit een historisch als uit een practisch oogpunt voor ons land niet zonder beteekenis zou zijn. Deze leden betwijfelden, of al te groote terughoudendheid van Nederland te dezen opzichte in 's Lands belang is te achten."

Het Koloniaal Weekblad van 23 Februari merkte hierbij op:

„Het is wel in hooge mate teleurstellend, dat slechts „eenige leden” hier hunne teleurstelling uitspraken. $\mathrm{Na}$ al wat er over deze kwestie is geschreven, had men van de Kamer wat meer belangstelling en krachtiger aandrang op de Regeering mogen verwachten. Wij vreezen, dat het antwoord van de Regeering voor de zooveelste maal ontwijkend zal zijn. Wellicht zal de Kamer dàn inzien, dat er een reden moet zijn waarom de Regeering al zoo vele jaren weigert in deze aangelegenheid het volle licht te laten schijnen."

Vóór het antwoord van den Minister van Koloniën ver- 


\section{scheen, gaf [Mr.] J. B. B[reukelman] in Het Vaderland van 25 Februari, Av.blad C, een overzicht van de Grens- regeling van Suriname, waarvan het slot aldus luidt:}

.... „Hoe noode ook, tenzij de regeering nog nadere mededeelingen doet, moet men zich, voorloopig althans, wel hierbij neerleggen. [n.l. bij de weigering der Regeering om de door den heer Van Kol verlangde inlichtingen te geven]. Verschillende omstandigheden, waarover de regeering zich hoogstwaarschijnlijk niet in het publiek wil uitlaten, kunnen tot deze gedragslijn aanleiding hebben gegeven. Het zou toch mogelijk zijn, dat onze regeering met Engeland onderhandelingen had aangeknoopt over deze aangelegenheid, maar dat over bepaalde punten nog verschil van meening bestond, dat niet dadelijk uit den weg kan geruimd worden; het ware bijvoorbeeld niet onmogelijk, dat de Engelsche regeering anders denkt over wat als bovenloop van den Corantijn te beschouwen is en niet geneigd is de zaak door scheidsrechterlijke uitspraak te doen beslissen. Trouwens Engeland kan bezwaar maken tegen de publicatie van hetgeen aan onze regeering gevraagd is. Nog andere gevallen zijn denkbaar, die de oplossing dezer zaak kunnen tegenhouden, al kan men Dr. Benjamins toegeven, dat de „groote omvang" der stukken nu wel niet als hoofdargument voor niet-openbaarmaking kan gelden."

De beschouwingen van Mr. B. meende ik niet onbeantwoord te mogen laten en verzocht daarom aan de redactie van Het Vaderland plaats voor het volgende stuk. (Zie het ochtendblad van 1 Maart):

Geachte Redactie,

Een kleine ruimte, please, in uw blad voor eenige opmerkingen naar aanleiding van het interessante artikel Grensregeling van Suriname van (Mr.) J. B. B.(reukelman) in uw avondblad van 25 Februari.

Mr. B. meent dat het antwoord van den Minister van Koloniën aan den heer van Kol op diens vraag betreffende de westgrens van Suriname hierop neerkomt, dat de regeering het niet in 's lands belang acht de verlangde inlichtingen te geven.

$\mathrm{Nu}$ zijn de wegen der diplomatie wel dikwijls onnaspeurlijk, maar ik acht den omweg, dien de Minister van Buitenlandsche Zaken zou hebben gekozen om te zeggen, dat de regeering het geven van de verlangde inlichtingen niet in 's lands belang acht, toch wel zeer ongewoon. Zijne Excellentie noemt toch geen ander bezwaar dan de uitgebreidheid der briefwisseling tusschen de beide regeeringen.

Voorgangers van dezen Minister hebben zich bij hun antwoorden op vragen in de Staten-Generaal over dezelfde kwestie gedaan, evenmin 
beroepen op 's lands belang. Ik betwijfel het dan ook ten sterkste of 's lands belang hier in het spel is.

Aan het slot van zijn artikel wijst Mr. B. op verscheiden mogelijkheden, die de gedragslijn der regeering kunnen verklaren. „Het ware bijvoorbeeld niet onmogelijk - aldus Mr. B. - dat de Engelsche regeering anders denkt over wat als bovenloop van den Corantijn te beschouwen is en niet geneigd is de zaak door scheidsrechterlijke uitspraak te doen beslissen." Dat Engeland de Koeroeni als den bovenloop van de Corantijn beschouwt, staat vast. Het is mij echter niet bekend dat onze regeering het ooit in het openbaar heeft uitgesproken, dat zij de Nieuwe Rivier voor de eigenlijke Corantijn houdt.

Of de Engelsche regeering afwijzend heeft geantwoord op een voorstel van onze zijde om de zaak door een scheidsrechter te doen beslissen, is mij niet bekend. Engeland is er niet gemakkelijk toe te brengen zulke vragen door een scheidsrechter te doen beantwoorden. Dat heeft het Britsch-Venezolaansche grensgeschil bewezen. Van den anderen kant is er geen soepeler regeering dan juist de Engelsche, waar het gaat om het loslaten van oude - zelfs eeuwenoude - opvattingen. Men denke aan de Iersche kwestie.

Aangenomen dat de Engelsche regeering een twintigtal jaren geleden niets voelde voor een scheidsrechterlijke uitspraak, dan is dit geen reden voor onze regeering om niet op de zaak terug te komen, waar het recht zoo evident aan onze zijde is. Er is inmiddels zoo veel in de wereld veranderd.

„Trouwens - zoo vervolgt Mr. B. - Engeland kan bezwaar maken tegen de publicatie van hetgeen aan onze regeering gevraagd is." Dit houd ik voor te eenenmale uitgesloten. De Engelschen zijn te handige diplomaten om de verdenking op zich te laden, dat er in hun diplomatieke correspondentie iets zou staan dat het daglicht niet zien mag. En heeft onze regeering de toestemming van de Engelsche regeering noodig voor de publicatie van dat deel der bescheiden, dat bijna 80 jaar oud is en wel als „geschiedenis” beschouwd mag worden?

Ik handhaaf mijn meening - zie de West-Indische Gids van November 1920 en December 1921 - dat de regeering tot de publicatie van alle bescheiden dient over te gaan. De uitgebreidheid daarvan is geen ernstig bezwaar en een ander heeft de Minister van Buitenlandsche Zaken niet geopperd.

Er zal misschien spoedig aanleiding zijn om op deze grenskwestie terug te komen. Een lid der Koloniale Staten heeft nl. tot den Gouverneur de vraag gericht of de eilanden in den mond van de Corantijn geheel of gedeeltelijk in concessie worden gegeven als houtgronden of kostgronden. Vroeger was dit wèl het geval. Ontwijkt de Gouverneur de vraag niet - en dat is van hem niet te verwachten - dan zal er wel het een en ander aan het licht komen.

Den Haag, 26 Februari. 
Hierop repliceerde $\mathrm{Mr}$. B. in Het Vaderland van 3 Maart, Av.blad C, als volgt:

.... „De wegen der diplomatie, zoo zegt dr. B. zijn onnaspeurlijk maar hij acht den omweg, door den Minister van Buitenlandsche zaken gekozen, om te zeggen, dat de regeering het geven van de verlangde inlichtingen niet in 's lands belang acht, toch wel zeer ongewoon. Ik weet er natuurlijk niets van, ik geef toe, dat het bezwaar, aan de uitgebreidheid der briefwisseling tusschen ons land en Engeland ontleend, op zichzelf wel niet kan geacht worden met 's lands belang in verband te staan, maar ik meen er op te moeten wijzen, dat het dikwijls voorkomt, dat om welke redenen dan ook, een regeering liever de uidrukking ,'s lands belang" niet wenscht te gebruiken.

Wanneer dr. B. zegt: Ik betwijfel dan ook ten sterkste, dat 's lands belang hier in het spel is, vergeet hij m.i., dat bijvoorbeeld een niet door Engeland geaccepteerd voorstel, door ons gedaan, om de zaak te regelen, ook uit anderen hoofde invloed op de politieke betrekkingen tusschen de twee landen kan hebben en dat daarom publicatie van hetgeen over deze zaak is voorgevallen, ongewenscht kan zijn. Ik bedoel natuurlijk niet publicatie van bescheiden, die tachtig jaar oud zijn, maar van bescheiden van meer recenten datum, waartegen Engeland mogelijk wel bezwaar kan hebben. Daarbij bedenke men - en dit heb ik mede bedoeld - dat het altijd tusschen bevriende staten gewoonte is elkander te polsen over publicatie van belangrijke documenten, die op onderhandelingen tusschen deze staten betrekking hebben of daarmede in verband staan.

Zooals uit mijn artikel blijkt, zou ik het ten zeerste toejuichen, wanneer deze publicatie kon geschieden; ik heb alleen naar redenen gezocht, waarom zij vooralsnog ongewenscht zou kunnen zijn.

Van groot belang is mij hetgeen dr. B. aan het slot van zijn artikel meedeelt, dat namelijk spoedig de zaak in de Koloniale Staten ter sprake zal komen."

Op deze beschouwingen heb ik niet geantwoord, geenszins evenwel omdat zij mij overtuigd hebben. Natuurlijk besef ik, dat er bezwaren van diplomatieken aard tegen publicatie der bescheiden kunnen bestaan, maar het is onmogelijk die te ontdekken in de antwoorden van den Minister op de vragen van den heer Van Kol. In die mate kronkelend zijn de wegen der diplomatie niet. Bestonden de door Mr. B. veronderstelde bezwaren inderdaad, dan ware het toch wel aan de Regeering gelukt een formule te vinden om dit kenbaar te maken. Men bedenke toch dat de weigering van den Minister ook betreft de 
correspondentie, die 80 jaar oud is, voor welker publicatie het toch inderdaad niet noodig is de Britsche regeering te polsen. Is er iemand onnoozel genoeg om te meenen, dat de Britsche regeering er aan zou denken de onze te polsen als zij bescheiden van zoo eerbiedwaardigen ouderdom wilde uitgeven?

Men zij overigens niet al te vlot, met het onderstellen van vrees voor openbaarheid bij de tegenpartij. Evenmin als in het particuliere leven is dit vleiend tegenover regeeringen. Ik voor mij geloof niet dat de Britsche regeering bezwaar zal hebben tegen openbaar maken van de hierbedoelde bescheiden.

In zijn Memorie van Antwoord (ingezonden bij brief van 8 Maart) op het bovengenoemde Voorloopig Verslag, schreef de Minister van Koloniën:

„De ondergeteekende ziet niet in, dat een praktisch belang zou zijn gediend met de openbaarmaking van de bescheiden, betreffende de in den loop der tijden gerezen geschillen omtrent de grenzen tusschen Suriname en de nabijgelegen vreemde koloniën. Aangezien voorts het historisch belang van eene zoodanige publicatie niet in die mate weegt, dat de kosten ten deze in het midden zouden mogen worden gelaten, acht de ondergeteekende zich niet verantwoord, om ten aanzien van de in het verslag gevraagde openbaarmaking aandrang uit te oefenen op zijn ambtgenoot van Buitenlandsche Zaken".

Minister De Graaff is blijkbaar gemaakt van het hout waaruit men diplomaten snijdt!

Men moet wel een extra-fijnen neus hebben om in dit antwoord iets te bespeuren van bezwaren van Engelschen kant.

De kroniekschrijver in Het Koloniaal Weekblad van 16 Maart kon er zich niet bij neerleggen en schreef:

„Het spel van kat en muis tusschen Staten-Generaal en Regeering wordt dus voortgezet! Zullen de Staten-Generaal daarin berusten? Wij hopen van niet.

In de eerste plaats willen wij hier aanteekenen, dat het niet gaat om de grenzen met de nabijgelegen vreemde koloniën, maar meer in het bijzonder met de Britsche kolonie.

Men kan met den minister van meening verschillen omtrent hetgeen een praktisch belang genoemd mag worden. Wij achten het een praktisch belang dat het eindelijk eens bekend wordt, hoe en wanneer er een 
grensregeling met Engeland getroffen is buiten medewerking van de Staten-Generaal in strijd met art. 1 van het Surinaamsche RegeeringsReglement. Wij achten het van praktisch belang aan de hand van de bescheiden te onderzoeken of die regeling niet ongedaan gemaakt moet worden. In verband ook met de gedachtenwisseling, over deze kwestie gevoerd in "Het Vaderland" van 25 Februari, Avondblad, 1 Maart, Ochtenblad en 3 Maart, Avondblad, vestigen wij er de aandacht op, dat de minister ook nu niet gewaagt van een bezwaar der Engelsche regeering tegen publicatie van de bescheiden. De minister van Buitenlandsche Zaken is er dezen keer buiten gelaten."

Ik heb mijzelf afgevraagd hoe de Minister uit de impasse zou geraken als het een of ander wetenschappelijk lichaam aanbood de publicatie voor zijne rekening te nemen, wat toch niet geheel onmogelijk is.

De ,eenige leden”, die in het Voorlopoig Verslag aan het woord waren hebben met dit antwoord van den Minister genoegen genomen. Bij de openbare behandeling van de begrooting op den avond van 29 Maart is er althans geen woord over gerept. Trouwens is het de vraag of de ,eenige leden"' behoorden tot de 9 (zegge negen), die ter vergadering waren opgekomen.

Op een teleurstelling is ook uitgeloopen de verwachting uitgesproken in mijn hiervoren genoemd artikeltje in Het Vaderland van 1 Maart. Het Koloniaal Weekblad van 20 April schrijft nl.: Staten:

De gouverneur heeft het volgend schrijven gericht tot de Koloniale

„Naar aanleiding van de in de missive van de Koloniale Staten van 15 Februari 1922 No. 47 gestelde vragen ten aanzien van de in de Corantijn gelegen eilanden, heeft de ondergeteekende de eer UhoogEdelGestrenge mede te deelen, dat zijnerzijds geen enkel bezwaar bestaat tegen de uitgifte van concessiën voor houtbewerking op het Papegaaieneiland en dat zoodanige uitgifte eerlang zal plaats hebben.'

Dus toch een diplomatiek antwoord! Het spijt ons voor Baron van Heemstra. De vraag heeft betrekking op „de in de Corantijn gelegen eilanden" en nu spreekt de Gouverneur leukweg alleen van het Papegaaien-eiland! Het spel van kat en muis wordt dus ook op het Plein te Paramaribo voortgezet. We hopen, dat de Koloniale Staten zullen willen weten hoe het staat met de uitgifte van concessiën op de andere eilanden." 
Het is met die eilanden in de Corantijn een eigenaardige geschiedenis. $\mathrm{Na}$ hetgeen ik daarover schreef in mijn artikel in het Tijdschrift van het Kon. Nederlandsch Aardr. Genootschap, December 1898 zal ik daarop niet terugkomen, maar slechts constateeren, dat ook van Engelsche zijde de geheele rivier met de daarin gelegen eilanden steeds beschouwd is als Nederlandsch gebied, en dat wel langer dan een eeuw. Nog op 29 Februari 1912 verklaarde in de Court of Policy de ProcureurGeneraal van Britsch-Guiana, in een vergadering die door den Gouverneur werd gepresideerd, dat ,it was a question of hard fact", dat de geheele Corantijn Nederlandsch territoir was, zoodat een boot, aan den Engelschen oever vastgebonden, feitelijk zich bevond op Nederlandsch gebied.

Van onze zijde waren er op verscheidene dezer eilanden houtconcessies uitgegeven. Mij is bekend dat zulke concessies zelfs waren verleend aan stroomannen van bewoners van den Engelschen oever, die toch niet dien omweg zouden gekozen hebben, wanneer zij meenden, dat zij die concessies ook van hun gouvernement konden verkrijgen. Onze rechters hebben meermalen stroopers op die eilanden veroordeeld. In het British Guiana Handbook I9I3, issued by the permanent Exhibitions Committee under the direction of His Excellency Sir Walter Egerton, K. C. M. G. kan men lezen:

„The Courantyne river ranks second in size amongst the rivers of the colony, of which its left bank forms the boundary."

Die "left bank" is de Britsche oever, hetgeen ook blijkt uit de bijgevoegde kaart van 1910, geteekend door L. S. Hohenkerk; dus de geheele rivier met de eilanden Nederlandsch. Maar op een kaart van Britsch Guiana "published by authority of his Excellency the Governor Sir Walter Egerton, by L. S. Hohenkerk, Government Surveyor 1913 - vreemd genoeg van hetzelfde jaar als het Handbook — verschijnt op eens deze aanteekening:

„The Eastern boundary of the Colony is the middle of the deepest channel (Thalweg) of the river Courantyne and when an Island is pass- 
ed the middle of the deepest channel (Thalweg) between the Island and the West bank of the river."

De rivier is hier niet meer in haar geheel Nederlandsch, maar de eilanden worden nog steeds als zoodanig beschouwd.

Zoo was door onze schuld de nieuwe opvatting in Britsch Guiana in 1913.

Maar in Engeland?

In 1920 - let wel: I920! - verscheen in Londen, published by H. M. Stationery Office, een serie Handbooks prepared under the direction of the. Foreign Office. No. 135 van de serie is gewijd aan Britsch Guiana. (Zie De West-Indische Gids, 3e jaargang, 1922, blz. 588).

Op blz. 39 lees ik: „The Corentyne, the boundary river of the colony, may de regarded as being Dutch".....

En daar komt zoo maar mir nichts, dir nichts Jhr. de Marees van Swinderen, toenmaals Minister van Buitenlandsche Zaken, in zijne Memorie van Antwoord op het Voorloopig Verslag der Eerste Kamer betreffende zijne begrooting voor 1913, deze verklaring afleggen:

„Grenzen van Suriname. De opmerking dat uit de laatst bekende nasporingen zou gebleken zijn, dat de New-River de eigenlijke Corantijn is en diensvolgens de grens zou vormen tusschen Suriname en Britsch Guyana, berust op een dwaling. Integendeel is het op gronden van historischen en volkenrechtelijken aard in overeenstemming met de Britsche Regeering als een uitgemaakte zaak te beschouwen dat die grens wordt gevormd door de Cutari-Curuni, op welken waterloop in zijn geheel toepasselijk zijn de gewone regelen van het volkenrecht ten aanzien van gemeenschappelijke grensrivieren geldende."

Zelden zijn met meer aplomb in weinige regels meer onjuistheden samengeperst. En het klinkt bijna als de triomfantelijke mededeeling aan den volke van een behaalde zege! Toch was het alles behalve een overwinning en het kost moeite, ook zonder de onthulling van den heer De Villiers - waarover later - in die „overeenstemming" iets anders te zien dan een diplomatiek euphemisme voor, om het in de volkstaal te zeggen, zich hebben 
laten beduvelen. In mijn artikel in de November-aflevering 1920 van dit tijdschrift heb ik er op gewezen dat de Minister in elk opzicht ernaast was. Aan de „overeenstemming" had hij geen schuld, zooals aanstonds blijken zal, maar wel is de verklarende mededeeling zijn werk of dat van een zijner ambtenaren, die op voet van oorlog staat met de aardrijkskunde. N'en déplaise wien ook is de New-River de eigenlijke Corantijn en zij behoort daarom de grens te zijn. Ik zal dat niet op nieuw gaan betoogen.

Was het dan in strijd met het volkenrecht dat de geheele rivier Nederlandsch was? Langer dan een eeuw hebben de Engelschen het feit erkend.

„It is, thirdly, possible - aldus L. Oppenheim. International Law. Second edition, London 1912, blz. 271 - that the boundary line is the border line of the river, so that the whole bed belongs to one of the riparian States only. But this is an exception created by treaty or by the fact that a State has occupied the lands on one side of the river at a time, prior to the occupation of the lands on the other side by some other State."

Precies deze uitzondering vormde de Corantijn. En, zooals ik reeds zeide, met instemming van de Engelschen gedurende meer dan een eeuw. Ik laat nu daar of deze toestand ook redelijk was. Mijn zienswijze daaromtrent heb ik uiteengezet in mijn artikel van 1898. Maar de Regeering had onze erkende rechten niet mogen prijsgeven zonder meer. Zou Engeland een toestand die langer dan een eeuw had bestaan en steeds door ons was erkend zoo maar hebben prijs gegeven? Het standpunt, door Lord Salisbury in de kwestie der bronrivieren ingenomen, bewijst immers het tegendeel.

Indien op een volgende kaart van Britsch Guiana de eilanden niet gedeeltelijk als Britsch gebied worden aangegeven dan zal dit alleen zijn omdat de afbakening van de grenslijn volgens de door Jhr. van Swinderen vermoedelijk bedoelde ,gewone regelen van het volkenrecht", schatten zou kosten. Wie zal de eilanden nu in concessie mogen uitgeven als daarom gevraagd wordt? Het bestuur 
van Suriname heeft alleen op het Papegaaieneiland, dat vlak bij onzen oever ligt, houtconcessies uitgegeven. Op de andere eilanden kan dat bijkbaar niet.

Het staat vast dat onze regeering tusschen 1899 en 1903 vertoogen heeft gericht tot de Britsche Regeering, naar aanleiding van de uitspraak van het scheidsgerecht in het geschil tusschen Venezuela en Britsch Guiana, vermoedelijk reeds in 1899 door den toenmaligen Minister van Buitenlandsche Zaken, Mr. de Beaufort, zooals Mr. Breukelman meedeelt in zijn artikel in Het Vaderland van 25 Februari $^{1}$ ). Diplomatieke onderhandelingen loopen niet af in een vloek en een zucht. Mr. de Beaufort trad af op 1 Augustus 1901. Hij heeft ze vermoedelijk niet ten einde gebracht. Waarschijnlijk heeft het vertoog van dezen bewindsman alleen geloopen over de kwestie van de bronrivieren van de Corantijn. En nu dringt zich hier de vraag op: heeft de diplomaat, die van onze zijde de onderhandelingen leidde, de - hoe zal ik het noemen? - tegemoetkomendheid zoover gedreven dat hij uit eigen beweging de kwestie van het bezit der rivier en der eilanden ter tafel heeft gebracht? Of heeft de Engelsche diplomaat, na in het vraagstuk van de bronrivieren onze regeering tot toegeven te hebben genoopt, den status der rivier in het geding gebracht en ook hierin „overeenstemming” afgedwongen? Zoolang de regeering de bescheiden niet openbaar maakt, verkeert men in het duister. En dit is jammer, omdat de gang van zaken after all een geheel andere kan geweest zijn. In geen van de beide genoemde gevallen toch zou onze diplomatie hebben blijk gegeven voor hare taak berekend te zijn geweest ${ }^{2}$ ). Uittrekken om

\footnotetext{
1) Tot hen, die krachtig hebben aangedrongen dat onze Regeering zich zou laten gelden behoorde ook Jhr. Mr. A. P. C. van Karnebeek. Zie zijn rede in de vergadering van de Tweede Kamer van 22 December 1899.

$\left.{ }^{2}\right)$ Dat grenskwestiën niet altijd veilig zijn in de handen van diplomaten zal wel geen tegenspraak ontmoeten. Ter illustratie twee aanhalingen:

„De Surinaamsche grenskwestie. In 1888 wordt aan de Tweede Kamer voorgelegd een ontwerp-verdrag, waarbij Frankrijk en Nederland overeenkomen den tsaar te verzoeken als scheidsrechter op te treden in het geschil over den loop der grens tusschen Fransch-Guyana en Suriname. In
} 
de New River als grens op te eischen, hierin falen en eindigen.... met de helft van de geheele rivier uit te leveren! Het zooeven aangehaalde antwoord van Minister de Marees van Swinderen geeft te denken.

Een bekwaam diplomaat - met wat haar op zijn tanden! - had moeten bereiken dat, tegenover ons prijsgeven van een lang bestaanden toestand, de Britsche regeering had toegestemd om de kwestie van den bovenloop aan arbitrage te onderwerpen.

De lezer wordt nu verzocht mij in gedachten naar Paramaribo te vergezellen. De Koloniale Staten behandelen

den tekst van dat verdrag is het geschil geheel verkeerd gedefinieerd en wel zoo, dat het Fransche standpunt daarin reeds van te voren vastgelegd wordt! Natuurlijk onzerzijds niet met opzet, maar omdat onze „diplomaten", de ministers van Koloniën en Buitenlandsche Zaken, geen juiste voorstelling hadden van den geografischen kant der kwestie.

Vooral de diplomaat bij uitnemendheid, de minister van Buitenlandsche Zaken, begreep absoluut niets van het geval. Dat kwam het sterkst uit bij het debat in de Tweede Kamer over zijn begrooting van 1889, toen hij de opdracht aan den scheidsrechter volkomen onjuist weergaf en het Kamerlid Veegens hem de juiste woorden in den mond moest leggen, die hij dan ook gehoorzaam napraatte.

Met al deze domheden moesten de Kamers toch het ontwerp-tractaat maar slikken. Zooals ook nu gezegd is: als die ontwerpen bij de Kamers komen, is er niet veel meer aan te doen. Men kan er dan niet meer aan wijzigen, tenzij men de onderhandelingen van voren af wil beginnen.

$\mathrm{Nu}$ zouden wij wel eens willen weten, wat er tegen zou zijn, wanneer in een geval als dit, over een grenskwestie, de zaak open en bloot in beide landen aan de openbare meening werd voorgelegd, zoodat ieder zich daarover een meening kon vormen, en men rekening kon houden met de meening van hen, die er wèl iets van begrepen."

(De Telegraaf van 11 Mei 1917).

In mijn artikel van 1898 (blz. 803) schreef ik:

„Het betwiste gebied [tusschen Lawa en Tapanahoni] is ons toegewezen zoowel op historische als op aardrijkskundige gronden; maar nu dringt zich onwillekeurig de vraag op hoe de beslissing zou zijn uitgevallen wanneer die gronden eens gebleken waren niet samen te vallen, d.i. wanneer het geval zich had voorgedaan dat men onze historische rechten niet kon ontkennen, maar tevens de Tapanahonie als de voortzetting van de Marowijne moest beschouwen."

Van onze zijde had men zich uitsluitend op historische gronden moeten beroepen. Wat de kwestie van de Corantijn betreft, daar heeft men in het brongebied te doen met een zuiver en zeer eenvoudig aardrijkskundig vraagstuk. De vraag of de geheele rivier Nederlandsch gebied is, kan niet anders dan op historische gronden beantwoord worden. 
de begrooting voor 1914. Op de vergadering van 5 Mei 1913 een interessant debat over de grenskwestie. De Procureur-Generaal, gedelegeerde van den Gouverneur, zal, de sprekers beantwoordende, zich, na hetgeen in de $\mathrm{Me}-$ morie van Antwoord is gezegd, van nadere besprekingen onthouden.

„Slechts wil hij opmerken dat deze zaak niet is beslist door den tegenwoordigen Minister van Buitenlandsche Zaken [dat was Jhr. de Marees van Swinderen] en ook niet zonder behoorlijke overweging van alles wat dienaangaande van verschillende zijde, met name Dr. Benjamins, is te berde gebracht. Reeds in het jaar 1903 is die beslissing tot stand gekomen, zoodat men bezwaarlijk van de tegenwoordige Regeering kan eischen om die beslissing te herzien."

Bij de repliek kon spreker nog mededeelen

„dat wanneer van den Minister verlof gekregen wordt om de correspondentie over deze aangelegenheid aan de Staten mede te deelen, de Gouverneur dit gaarne zal doen, als wanneer dan blijken zal dat de beslissing in deze niet zoo lichtvaardig genomen is, dat zij in overeenstemming is met het advies van den Raad van State. Spreker is overtuigd dat men na kennisneming dier correspondentie zal erkennen dat de genomen beslissing op degelijk gronden rust."

Dat verlof van den Minister is blijkbaar nooit ontvangen. Ik heb ten minste niets meer van de zaak vernomen, hoewel ik steeds van het verhandelde in de Koloniale Staten op de hoogte bleef.

Reeds in 1903!

Toen was Mr. R. Melvil Baron van Lijnden Minister van Buitenlandsche Zaken, die in Maart 1905 aftrad wegens verschil van gevoelen met den Minister van Binnenlandsche Zaken, Dr. A. Kuyper.

Waarom is die ,overeenstemming”, zoowel hier als in Suriname, niet eerder bekend gemaakt dan in 1913? Dus na 10 jaren! En dat nog wel incidenteel!

Naar aanleiding van de verklaring van den ProcureurGeneraal verscheen in Het Koloniaal Weekblad van 12 Juni 1913 een uitvoerig artikel onder het opschrift Mysterie, waarin aangetoond werd dat de verklaring niet klopte met na 1903 tusschen Regeering en StatenGeneraal gevoerde gedachtenwisselingen. In Mei 1907 verscheen het Voorloopig Verslag van de Tweede Kamer 
betreffende het verdrag tusschen Nederland en Brazilië, waarin verklaard werd, dat men in de Memorie van Antwoord gaarne zou vernemen

„of de Regeering ook eenige mededeeling kan doen met betrekking tot eene eventueele regeling van de grenzen tusschen Suriname eenerzijds en Fransch en Engelsch Guyana anderzijds, en, zoo mogelijk, op welke grenzen onze kolonie naar het oordeel der Regeering aanspraak mag maken." ....

Een eventueele regeling!

Dit werd geschreven vier jaren nadat, volgens de verklaring van den Procureur-Generaal van Suriname, de beslissing gevallen was! Als er iets blijkt uit het verzoek van de Tweede Kamer, dan toch dit, dat men in de meening verkeerde dat de grensregeling ook met Britsch Guiana nog komen moest.

Zeer diplomatiek-ontwijkend - waarom toch? - werd aan de Kamer geantwoord:

.... „Aangezien, zooals hierboven is uiteengezet, de regeling der grenzen van Suriname eenerzijds en Fransch- en Britsch Guyana anderzijds geenerlei invloed op de onderhavige regeling kan hebben meenen de ondergeteekenden, [de Ministers van Buitenlandsche Zaken en van Koloniën] dat de aangelegenheid der Nederlandsch-Britsche en der Nederlandsch-Fransche grens hier buiten beschouwing kan blijven."

Uit dit antwoord kon de Kamer bezwaarlijk de wetenschap putten dat de grens met Britsch Guiana reeds in 1903 geregeld was.

Bij de Memorie van Antwoord was een kaart gevoegd, die de Kamer in haar meening moest versterken dat de grensregeling nog in de toekomst lag; de kleuren, die de grenzen tusschen de koloniën aangeven, eindigden nl. bij de samenvloeiing van de Koeroeni en de New River.

Maar de leden der Tweede Kamer waren niet de eenigen die niets wisten van een beslissing van $1903^{1}$ ).

$\left.{ }^{1}\right)$ Terwijl ik schrijf komt mij in handen de mail-editie van de Nieuwe Rotterdamsche Courant van 22 Mei 1906, waarin van bij uitstek deskundige hand, een artikel over de Grensregeling van Suriname. Ik lees daar: .... ,Die onzekerheid is echter nog grooter aan den Engelschen kant. De Oostelijke bronrivier van de Korantijn wordt, naar Schomburgk, gewoonlijk voor de grens gehouden; volgens latere onderzoekingen van C. Barrington Brown is echter de westelijke „New River” de eigenlijke bovenloop van deze grensrivier". .... 
In mijn artikel in De West-Indische Gids van November 1920 deelde ik mede hetgeen voorgevallen is op de bijeenkomst van 6 December 1911 van de "Society of Arts" te Londen, onder praesidium van Lord Reay. Ik had dat ontleend aan een verslag in de Nieuwe Rotterdamsche Courant. Ik heb nu het officieele verslag van de bijeenkomst voor mij liggen (Journal of the Royal Society of Arts, $\mathrm{N}^{\circ}$. 3081, Vol. LX. Dec. 8. 1911) en zal daaruit het een en ander overschrijven, dat bewaard dient te blijven:

Nadat de heer J. A. J. de Villiers (Superintendent of the Map Room, British Museum, Hon. Secretary of the Hakluyt Society) zijne lezing over British Guiana and its founder Storm van 's-Gravensande geëindigd had, ontspon zich een debat tusschen hem, Sir Everard Im Thurn, K. C. M. G. - een der beste kenners van Britsch Guiana - en den voorzitter, Lord Reay. Sir Everard zeide aan het slot zijner opmerkingen:

.... „The author had stated that the boundary between British Guiana and Spanish Guiana, or Venezuela, had been definitely settled, and the boundary between British Guiana and Portuguese Guiana, or Brazil, had also been settled; but, curiously enough, the whole of the boundaries of British Guiana had not even yet been settled. There was still some considerable difference of opinion with regard to the boundary on the Upper Corantyne between British Guiana and what was still Dutch Guiana, or Paramaribo [sic]. The question had been raised as to where the boundary existed there, but it had never been settled up to the present day, so that it was not quite accurate to say that British Guiana now enjoyed a definite boundary." ....

Dit werd gezegd in 1911!

Lord Reay verklaarde:

.... „He was glad to hear from Sir Everard Im Thurn's remarks that there was a chance of still another arbitration taking place, which he hoped would be as successful as its two predecessors, for settling the frontier. He had no doubt that an arbitration between the Netherlands and Britain with regard to the frontier which had not yet been settled would be of the most amiable kind, and would have the same result that all arbitrations hitherto had had between various nations, namely, to render the subsequent relations of the two countries more friendly and cordial." 
De beide sprekers beantwoordende, bracht de heer De Villiers het volgende in het midden:

.... „With regard to the boundary that was not yet settled, he had always heard that is was a tradition in the Foreign Office that Lord Salisbury would not allow there was any question about the matter at all; that he regarded that piece of boundary as finally settled; and that, however much the Netherlands might be disposed to open the question, this country would always resolutely set its face against it. If, however, such an arbitration was held, he would be only too happy to place his services at the disposal of the Government."

Is de Nederlandsche regeering voor deze „traditie” gezwicht? En heeft men dat genoemd ,overeenstemming"? Hoe het ook zij, Lord Salisbury is in 1903 overleden juist in het jaar van de ,overeenstemming" - en met hem misschien ook de bulldog-traditie van de Foreign Office.

$\mathrm{Na}$ het voorgaande en hetgeen ik in vroegere artikelen heb betoogd, behoef ik wel niet te verzekeren, dat, naar mijne meening, de regeling van 1903, die buiten medewerking van de Staten-Generaal getroffen is, moet worden herzien. Een regeling waarvan de grondslag is een foutieve opvatting van de beteekenis van een haastige, te eenenmale onvoldoende exploratie van Schomburgk ${ }^{\mathbf{1}}$ ) kan en mag niet gehandhaafd worden ${ }^{2}$ ).

Onze Minister van Buitenlandsche Zaken schrome niet het illustere voorbeeld te volgen van wijlen Lord Salisbury, dat ik aan het slot van mijn artikel van December 1921 in herinnering heb gebracht ${ }^{3}$ ).

$\left.{ }^{1}\right)$ Leefde Schomburgk nog, dan zou hij, voortreffelijk geograaf die hij was, zelf onthutst zijn van de beteekenis, die men aan zijn haastig afzakken van een rivier gegeven heeft. Men zie over zijn opneming van het brongebied van de Corantijn ook de opmerkingen van C. H. de Goeje in het Verslag der Toemoekhoemak-Expeditie, 1908, blz. 156 en 157.

$\left.{ }^{2}\right)$ Het andere deel van de „overeenstemming” blijve zoo. Alleen zou het - om een zee van moeilijkheden te voorkomen - overweging verdienen de eilanden aan Suriname te laten.

3) Een gelukkig omen:

Terwijl ik dit schrijf komt mij in handen het Handboek voor de kennis van Nederland en Koloniën, samengesteld met medewerking van verschillende departementen van algemeen bestuur en uitgegeven door het Departement van Buitenlandsche Zaken (Directie van Economische Zaken). 
Maar daaraan ga vooraf de openbaarmaking van alle bescheiden.

In een artikel in De Gids van 1892, deel I blz. 340 schreef Mr. W. H. de Beaufort over Sir Joseph Yorke, den Engelschen gezant:

.... „Gedurende zijn langdurig verblijf te 's Gravenhage, hadden de Hollandsche Staatslieden, met wie hij dagelijks verkeerde, er niet toe bijgedragen om hem een gunstiger opvatting te doen huldigen. Hij had hen leeren kennen als zwakke, besluitlooze mannen, die onder het besef van de weerloosheid van hun land, elke verwikkeling met eene buitenlandsche mogendheid met angst tegemoet zagen."

Op 3 April van dit jaar sprak Mr. J. Limburg in een bijeenkomst van „Die Haghe” over den Haag als internationaal centrum. Volgens het verslag in de Nieuwe Rotterdamsche Courant van 14 April zeide hij:

.... „In deze eeuw [de 18de] hadden wij of Engeland of Frankrijk te volgen en beide lieten hun diplomaten op de Republiek los .... $\mathrm{Na} 1840$ had men nog slechts één gedachte: zich stil te houden op diplomatiek terrein." 1 )

Dit alles behoort tot de geschiedenis. Gezanten als Sir Joseph Yorke en Hollandsche Staatslieden als die hij hier

Met 19 kaarten en 34 afbeeldingen. 's Gravenhage, Martinus Nijhoff, 1922.

Een der 19 kaarten is een buitengewoon mooie kaart van Suriname, die ook in de Encyclopaedie van Nederlandsch West-Indië is opgenomen en waarin deze aanteekening is geplaatst: „Het ongekleurde gebied tusschen Nieuwe Riv. en Coeroeni Riv. en tusschen Litani Riv. en Marowini Riv. nog betwist."

$\left.{ }^{1}\right)$ Niet alleen na 1840. Zie hier ter illustratie een geval van diplomatieke haasvreterij - toevallig juist in een Surinaamsche grenskwestie! — dat ik ontleen aan een voortreffelijk artikel van wijlen Mr. A. Telting in de Nieuwe Rotterdamsche Courant van 13 Juni 1900, Eerste blad. B.

De Franschen hadden bij herhaling getracht de grenzen van hunne kolonie in Guiana te onzen nadeele te verplaatsen.

...., „Den 8sten October 1766 zag de posthouder Hausman van den Nederlandschen post in de Marowijne, hoe aan de overzijde der rivier een detachement Franschen, ook met geschut gewapend, was aangekomen, en nadat hij zich met hen in betrekking had gesteld, vernam hij tot zijne niet geringe verwondering, dat men het voornemen had, er eene redoute aan te leggen. Onmiddelijk zond hij bericht naar Paramaribo.

In plaats van nu dadelijk maatregelen te nemen, schreven Gouverneur en Raden 21 Oct. naar Amsterdam om van de directeuren te vernemen, wat er te doen stond; deze richtten zich weder tot de Staten-Generaal, en 
vond zijn thans ondenkbaar. Wij volgen nu niet Engeland of Frankrijk. Wij zijn ons zelven. De plaats die Nederland met zijn groot overzee-gebied in de rij der Staten inneemt is thans een geheele andere. Wij genieten aanzien in de wereld en verdienen dat. Nederland zal niet langer als kleine mogendheid worden beschouwd, dan het zelf wil.

Zeide niet Minister van Swinderen bij de installatie van de commissie voor de derde vredesconferentie dat Nederland in zake als deze ,het recht en de verplichting (heeft) om groote mogendheid zich te toonen"?

En schreef Mr. C. van Vollenhoven in 1913 niet dat zijn boekje (De Eendracht van het Land) preekte „dat vóór het einde van 1913 ons land na twee honderd jaar verval, zijn internationale rol moet hebben hernomen"?

Wij schrijven nu 1922.

Van schroom om bij de Britsche Regeering een zaak van recht aanhangig te maken mag en kan geen sprake zijn. Onze Minister van Buitenlandsche Zaken steke de voelhoorns uit en ik twijfel niet of de Britsche Regeering, die van geheel andere mentaliteit is dan twintig jaren geleden, zal hem welwillend tegemoet treden, als zij eenmaal inziet dat het alleen en uitsluitend te doen is om een vraag van recht. Immers bevat het gebied tusschen Koeroeni en New River, voor zooveel bekend, niets dat de begeerlijkheid van wien ook zou kunnen opwekken. Ten tijde van Schomburgk en later van Barrington Brown was het geheel onbewoond en dat is het nog steeds.

na nog meer geschrijf besloot men 5 Juni 1767 den ambassadeur in Frankrijk te gelasten zich bij het Hof van Versailles te beklagen. Maar niet met een formeel protest zou hij beginnen, hij moest ,,,,daarover iets op discrete en convenabele wijze insinueeren."'

En dat terwijl wij in ons volste recht waren!

Een 40-tal jaren vroeger had men in Suriname van meer durf blijk gegeven. Mr. Telting schreef: ....,,toen in 1725 door de Indianen van de Marowijne klachten werden ingebracht over bedreigingen van Fransche missionarissen, besloten Gouverneur en Raden, bij resolutie van 23 Juli, niet alleen geweld met geweld te doen keeren, maar ook om ,,,de Franschen te beletten haare limieten verder uyt te strekken en de van althoos herwaarts vastgestelde limietscheijdinge deeser landen, sig strekkende tot aan de rivier Senemary te conserveeren, aldaar weder gelijk voor deesen een vaste post te maeken."', 
En wat een prachtig gebaar en welk een heerlijke les voor de menschheid zou het zijn indien het voorstel om de vraag Koeroeni of New River aan de beslissing van een scheidsrechter te onderwerpen uitging van den sterkere, van Engeland. Maar het zou haast te mooi zijn. Wij kunnen daarop niet wachten. Het initiatief ga uit van onzen Minister van Buitenlandsche Zaken.

Excellentie, do it to day!

Of is, naar uw inzicht, het oogenblik niet goed gekozen, nu er zooveel wereldproblemen op oplossing wachten, laat dan uitstel geen afstel worden.

In de kwestie van de oostgrens zijn wij door den scheidsrechter in het gelijk gesteld. Niet anders zal het zijn met de westgrens.

Den Haag, Juli 1922. 